\title{
Universidade de direito canônico, esperança para a Amazônia
}

Canon law university, hope for the Amazon

Marcos Tonial ${ }^{1}$

Muito se tem discutido, recentemente, acerca do Código Canônico de 1983 e dos documentos do Santo Padre o Papa, como o Veritatis Gaudium, sobre a criação das Universidades Católicas interligadas à Igreja para a adequação das normativas e entrada de leigos(as), religiosos(as), para trabalhar em prol da promoção da pessoa humana e da cultura de cada povo.

Dentro deste artigo será analisada a importância de se criar faculdades de Direito Canônico na região amazônica, tendo presente a relevância dada àquela região após o sínodo da Amazônia, quando, naquela ocasião, o Papa Francisco fez a Exortação "Querida Amazônia"2. Também serão apresentadas as contribuições dessas universidades para a formação dos homens.

Em se tratando da formação das universidades de direito canônico, Francisco exorta que, na história da Igreja, o cristianismo

\footnotetext{
${ }^{1}$ Graduado em Filosofia pela Fundação Educacional de Brusque - FEBE. Graduado em Teologia pelo Centro Interdiocesano de Teologia de Cascavel, conveniado à Pontifícia Católica do Paraná - PUC/PR: Religioso da Diocese de Palmas-Francisco Beltrão. Vigário Paroquial na Paróquia Santa Rita de Cassia em Marmeleiro - Pr.

2 FRANCISCO. Exortação apostólica pós-sinodal "Querida Amazônia”. In: L'OSSERVATORE ROMANO. 02 fev. 2020.
} 
não é o único modelo cultural, e que os evangelizadores devem tomar cuidado para não se esquecerem de que os povos têm uma cultura, e não tentar impor a sua; conclui dizendo que não é para termos medo e não cortarmos as asas do Espírito Santo ${ }^{3}$. Não poucas vezes, a ciência canônica é criticada e chamada a dar resposta, porque sua visão não faz parte da natureza da Igreja. Nisso a opção foi sobrepor as necessidades pastorais às jurídicas.

O Papa Francisco nas suas alocuções tem insistido que o direito canônico deve ter sua dimensão pastoral ao pensar a dimensão pastoral do direito canônico. Ele lembra, ainda, que tal dimensão é precária na Amazônia em razão de fatores como a grande extensão territorial, a ampla diversidade de cultura e os graves problemas sociais. Contudo, isso não pode deixar a igreja indiferente e sem dar uma resposta ${ }^{4}$. Diante disso, insiste que a justiça aplicada à Igreja não deve ser feita meramente de despachos burocráticos; ou seja, o direito tem sua especificidade dentro da Igreja a que pertence.

No contexto das críticas recebidas pela Igreja, já em 1972, Paulo VI cita o elemento jurídico, como elemento da Igreja, opondose a algumas interpretações do Concílio Vaticano II, as quais estavam indo contra a existência do direito canônico como tal. Pautado no decreto Optatam Totius 16, é possível perceber que, a partir do mistério da Igreja, há uma ciência canônica que continua sendo um saber científico-jurídico. Entretanto, não é conveniente considerá-la como uma disciplina teológica ou pastoral ${ }^{5}$.

No Concílio Vaticano II, o interesse era que as universidades e faculdades católicas espalhassem-se pelo mundo, não teologicamente, mas sim com um curso dedicado ao estudo da ciência do direito canônico, facilitando a abertura das portas da educação para jovens e adultos, leigos e sacerdotes, homens, mulheres e religiosas; dando

${ }^{3}$ Ibid, n. 69.

${ }^{4}$ FRANCISCO. Exortação apostólica pós-sinodal "Querida Amazônia”. 02 fev. 2020 , n. 85.

${ }^{5}$ GERALDO, Denilson. A eclesialidade e metodologia da ciência canônica. In: REVISTA SCIENTIA CANONICA, v. 2, n. 4, 2019, p. 34-35. 
todo o suporte intelectual e espiritual para que, após a formação, essas pessoas sejam e estejam aptas ao trabalho de seu magistério em sua diocese (comunidade) ou além das fronteiras.

Iniciado com o Concílio Vaticano II e com os documentos apresentados até os dias atuais do Santo Padre Papa Francisco, a reforma dos estudos eclesiásticos abriu de forma harmônica a mente dos alunos ao mistério de Cristo, criando homens que enxerguem a si próprios; enxerguem além da Igreja e suas necessidades, fazendo que assim consigam ajudá-la em qualquer lugar do mundo, não somente com a evangelização, mas cuidando das questões sociais, orientando sobre comunhão, relacionamentos e partilhas, associando que Deus, a Igreja e seus membros são uma só pessoa.

Nesse contexto de interação entre a Igreja e seus membros, na Exortação Apostólica Evangelii Gaudium, Francisco conclama para que o povo seja escutado, para descobrir quais são seus anseios. Quando o pregador e/ou evangelizador torna-se além de um "contemplativo da Palavra e também um contemplativo do povo", ele começa a perceber as riquezas e as limitações desse povo. "Esta preocupação não é ditada por uma atitude oportunista ou diplomática, mas é profundamente religiosa e pastoral."

"A evangelização obedece ao mandato missionário de Jesus: 'Ide, pois, fazei discípulos de todos os povos, batizando-os em nome do Pai, do Filho e do Espírito Santo, ensinando-os a cumprir tudo quanto vos tenho mandado.' (Mt 28,19-20). Nesses versículos, aparece o momento em que o Ressuscitado envia os seus a pregar o evangelho em todos os tempos e lugares, para que a fé n'Ele se estenda a todos os cantos da terra."’7. Olhando para esse mandato de Jesus Cristo, não há como a Igreja ignorar essa orientação e não se fazer presente na Amazônia, com uma instituição de ensino, para ouvir, formar e ajudar o povo que tem suas necessidades pautadas nas normas canônicas.

\footnotetext{
${ }^{6}$ FRANCISCO. Exortação apostólica evangelii gaudium. 24 nov. 2013. In: $A A S$ 27, n. 154, 2013.

${ }^{7}$ Ibid., n. 19.
} 
Nesse sentido, se deixarmos de olhar somente com um olhar canônico e olharmos com um olhar civil, ou do direito civil, veremos o princípio da proporcionalidade ou razoabilidade; tal princípio prevê que todos devem ser atendidos em suas necessidades, como "justiça, equidade, bom senso, prudência, moderação, justa medida, proibição de excesso, direito justo e valores afins" ". Assim, não tem como deixarmos de refletir sobre este tema inerente àquela porção do povo da Amazônia que está muitas vezes excluído, longe dos centros de educação. Tais instituições de ensino canônico trariam uma proximidade maior à reflexão em termos canônicos, e tais formados poderiam auxiliar o povo dentro de seu contexto cultural, moral e ético, com seus costumes e tradições.

Francisco, ainda, cita: "Vivemos numa sociedade da informação que nos satura indiscriminadamente de dados; todos postos ao mesmo nível, e acaba por nos conduzir a uma tremenda superficialidade no momento de enquadrar as questões morais. Por conseguinte, torna-se necessária uma educação que ensine a pensar criticamente e ofereça um caminho de amadurecimento nos valores."

Diante desse contexto, devemos lembrar que tanto na pregação, quanto no ensino, a Igreja deve ensinar como a mãe que fala com seu filho, sabendo que o filho tem confiança de que tudo o que se lhe ensina, corrige ou valoriza é para seu bem. Portanto, tanto na pregação como no ensino, no coração da cultura do povo encontramos o modo mais apropriado de dizer e sobre o que dizer: "Assim como todos gostamos que nos falem na nossa língua materna, assim também, na fé, gostamos que nos falem em termos da cultura materna, em termos do idioma materno (cf. 2Mac7, 21-27), e o coração dispõese a ouvir melhor. Essa linguagem é uma tonalidade que transmite coragem, inspiração, força, impulso."10.

\footnotetext{
${ }^{8}$ LENZA Pedro. Direito constitucional: esquematizado. São Paulo: Saraiva, 2015, p. 184.

${ }^{9}$ Op. cit., n. 64.

${ }^{10}$ FRANCISCO. Exortação apostólica evangelii gaudium. 24 nov. 2013. In: AAS 27, 2013, n. 139.
} 
Em decorrência dessa realidade, em 2002, a Congregação para a Educação Católica publicou um decreto, regulamentando os programas de ensino de direito canônico nas faculdades. Contudo, alguns questionamentos vêm à tona sobre a natureza, o conteúdo e o método. Percebendo a grandiosidade da necessidade do estudo do direito canônico, o Papa Francisco, em 2017, com a Constituição Apostólica Veritatis Gaudium, vem mostrar e garantir a qualidade que deve ter o ensino de direito canônico, para que os que se formarem estejam a serviço da investigação e se formem para o magistério, estando preparados para assumir encargos eclesiásticos.

Para concluir, Francisco "insiste sobre a missão evangelizadora da Igreja e sua relação com o vasto e diversificado sistema das universidades e da ciência." ${ }^{11}$. Pensando no amplo território brasileiro, ainda são muitas regiões que necessitam de pessoas formadas em direito canônico, para a organização dos tribunais eclesiásticos e os trabalhos nas cúrias. $\mathrm{O}$ direito canônico tem sua especificidade e sua identidade; entretanto, não deixa de ter seu caráter pastoral com suas fontes teológicas e bíblicas.

Diante do exposto, uma Instituição de Ensino de Direito Canônico, na Amazônia, traria em voga todo o clamor da Igreja, nos últimos tempos, que busca considerar a pessoa em sua totalidade, inserida em sua cultura, "onde a Igreja se exercita na interpretação da realidade que brota do evento Jesus Cristo e se nutre dos dons da Sabedoria e Ciência que tornam valores imprescindíveis para uma "Igreja em saída."."

${ }^{11}$ GERALDO, Denilson. A eclesialidade e metodologia da ciência canônica. In: REVISTA SCIENTIA CANONICA, v. 2, n. 4, 2019, p. 42.

${ }^{12}$ Ibid., p. 43. 